\title{
The Effect of Handover on UMTS Services
}

\section{Teeb Hussein Hadi}

Baqubah Technical Institute, Middle Technical University, Baghdad, Iraq

eng_teebhussein@yahoo.com

\begin{abstract}
Mobility is an important factor in cellular networks so handover should be used to avoid the termination of call when user signal travel from cell to another in UMTS network. In this paper, the OPNET modeler 14.5 was used to simulate two scenarios of UMTS network the first one with handover support and the second without and study the effect of handover on performance factors such data traffic sent and data traffic received on FTP, HTTP and E-mail and the results appear that handover is very important to use with mobile cellular networks.
\end{abstract}

Key words:Cellular networks, UMTS, Handover , FTP , HTTP, E-mail.

\section{INTRODUCTION}

In telecommunication system, handover occurs to avoid termination of call when the user moving from one cell to another in very fast mode by releasing the connection from the oldcell and establishing a new connection to a new cell [1]. If new connection is established before old connection is released (break beforemake), data reception is interrupted for a short period of time and can be avoid the service disruption by establishing connections simultaneously by a mobile host to multiple access points and the connect to new cell before breaking its connection from the old cell (make before break) [2]. Handover necessary for mobility and user preferences. Handover will occur when received signal level drops below a certain threshold value and Actually consider a time average of the received signal instead of the instantaneous level [3]. In order to get the high quality of service with faultless communicationin a network, handover should be implementation. In telecommunications systems the second generation suffered from low data rate so the third generation mobile systems (UMTS) are needed to replace the old systems so in this paper we study and analysis the effect of handover on UMTS services like HTTP, FTP and E-mail by simulating the network in OPNET modeler 14.5.

\section{THE TYPES OF HANDOVER}

Depending on W-CDMA technology, there are three basic types of handover: hard handover, soft handover and softer handover 
DOI: https://dx.doi.org/10.26808/rs.ca.i7v6.07

International Journal of Computer Application (2250-1797)

Volume 7- No.6, November-December 2017

\subsection{HARD HANDOVER}

This type of handover occurs when user signal transfer from one cell to another that means the connection between the UE and the first Node-B is broken and established a new connection between the UE and new Node-B [4].

\subsection{SOFT HANDOVER}

This type of handover occurs when the user signal connected with more than one BS (NodeB) simultaneously [5].

\subsection{SOFTER HANDOVER}

This type of handover occurs when one BS receive from two adjacent sectors two UE through multi-path propagation [6].

\section{UNIVERSAL MOBILE TELECOMMUNICATIONS SYSTEM (UMTS)}

Is the third generation of mobile telecommunication system that developed by ETSI (European Telecommunications Standards Institute). It is provide multimedia services like voice, video and data, with ensured QoS up to a capacity of $2 \mathrm{Mb}$ per user by achieving a novel architecture for its radio access network, called UTRAN [7].It supports both Time division Duplex (TDD) and Frequency division Duplex (FDD) performing different operations. It is based on the IP technology having user achievable peak data rate of $350 \mathrm{kbps}[8]$.

\section{THE COMPONENTS OF UMTS NETWORK}

The UMTS network consists of three domains: The User Equipment (UE), the UMTS Terrestrial Radio Access Network (UTRAN) and the CoreNetwork (CN). UEis a collection of a variety types of equipment with different levels ofemployment such as PDAs, cellular phones, laptops, etc. it is consists of two parts: Mobile Equipment (ME) and Subscriber Identity Module (USIM)[9].UTRAN is an encompass term of for the Radio Network Controllers and Node B's. This communications network can carry traffics frequently to IP based Packet Switched from Circuit Switched. It is a point of contact between UE and a CoreNetwork [10]. CoreNetworkdomainconsists of two parts: Packet Switched and Circuit Switched that plays a basic role in mobile communication system to provide a necessary capabilities as switching and routing,mobility management, charging and billing, call and session control and security protection [11].

\section{THE PROPOSED NETWORK AND COMPONENTS}

The simulation model for the UMTS network under study is illustrate in (Figure 1).It consists of "3" servers (FTP server, HTTP server and E-mail server) that connected to hub, router, GGSN, "2" SGSN, "4" RNC and "12" Node-B each of them has "3" UE connected with it.Application definition symbols also used to specify application using available application types, names and the corresponding description in the process of creating our application like HTTP, FTP, E-mail and specify the encoder parameters for each of encoder schemes while creating the user profiles on theprofile definition symbol to generate application layer traffic.Two scenarios of UMTS network are implemented: the first one with handover support and the second withouthandover support to study the effect of handover on performance factorssuch data traffic sent and data traffic received on FTP, HTTP and E-mail. 


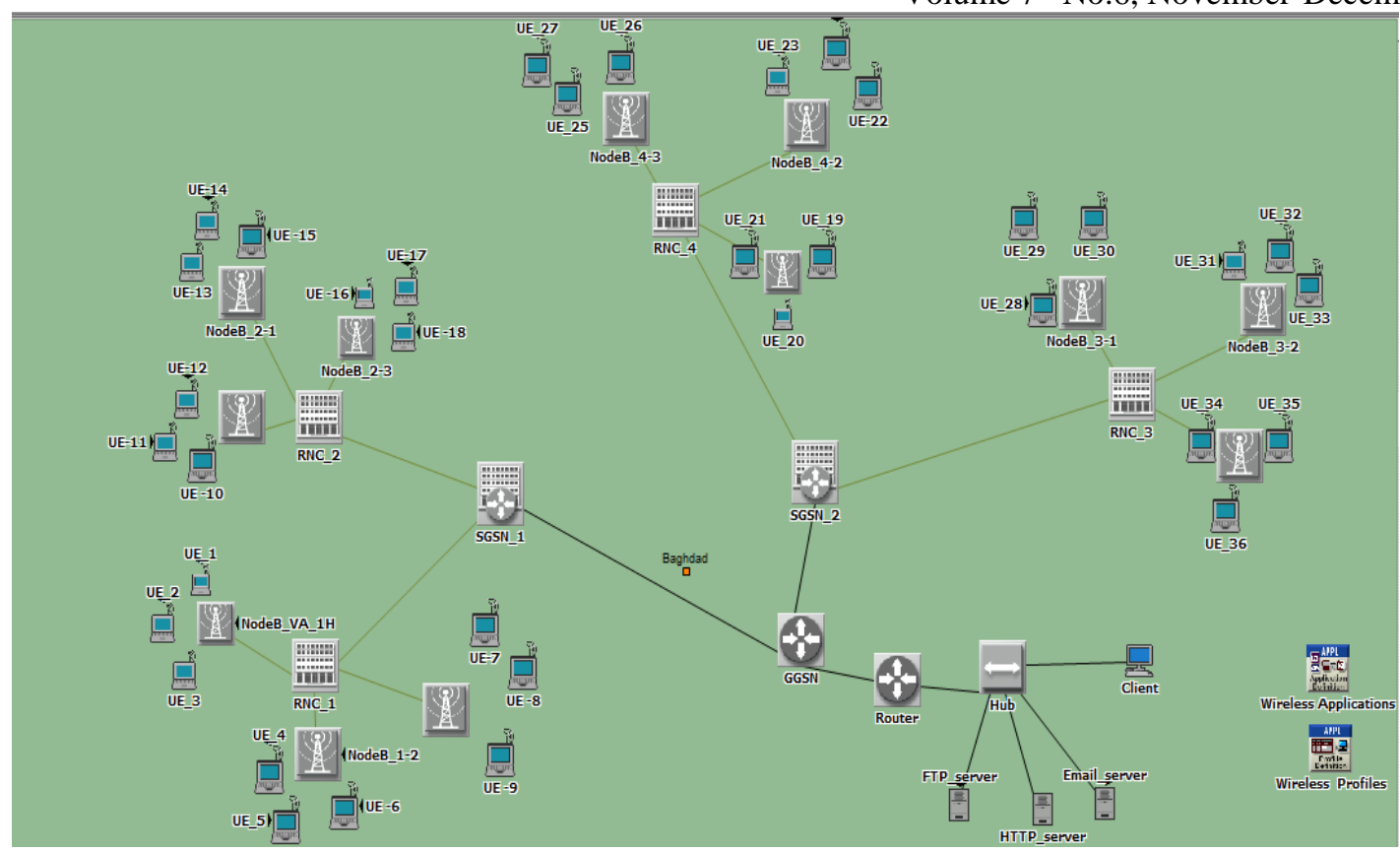

Fig1. Simulation the Proposed UMTS Network

\section{NETWORK SIMULATION RESULTS AND DISCUSSIONS}

In our UMTS subnet there are three servers as in the interactive class and there are three type of the traffic: FTP, HTTP, E-mail. The performance metrics that the paper is concerned with are: data traffic send (byte/sec) and data traffic received(byte/sec). The duration of simulation is 3600 minutes and 512 for seed. All figures signals started after $(15 \mathrm{sec})$ of the simulation time because all UE needed some time to connect with nearest Node-B.The blue line represent the UMTS network with handover support and the red line representthe UMTS network without handover support and the results are summarized in table1.

Figure (2): show that the data traffic sent signal for E-mail(Average bytes per second traffic submitted to the transport layers by all E-mail applications in the network) reach to (4513 byte/sec) with handover support and without handover support reach to $(2672 \mathrm{byte} / \mathrm{sec})$.

Figure (3): show that the data traffic receive signal for E-mail (Average bytes per second forwarded to all E-mail applications by the transport layers in the network) reach to (5569 byte/sec) with handover support and without handover support reach to (2451 byte/sec).

Figure (4): show that the data traffic sent signal for FTP (Average bytes per second submitted to the transport layers by all FTP applications in the network) reach to (21018 byte/sec) with handover support and without handover support reach to $(2672 \mathrm{byte} / \mathrm{sec})$.

Figure (5):show that the data traffic receive signal for FTP (Average bytes per second forwarded to all FTP applications by the transport layers in the network) reach to (19629 byte/sec) with handover support and without handover support reach to (13974 byte/sec).

Figure (6): show that the data traffic sent signal for HTTP (Average bytes per second submitted to the transport layer by all HTTP applications in the network) reach to (5683 byte/sec) with handover support and without handover support reach to (4232 byte/sec).

Figure (7): show that the data traffic receive signal for HTTP (Average bytes per second forwarded to the HTTP applications by the transport layers in the network) reach to $(5259 \mathrm{byte} / \mathrm{sec})$ with handover support and without handover support reach to (4612 byte/sec). 
DOI: https://dx.doi.org/10.26808/rs.ca.i7v6.07 International Journal of Computer Application (2250-1797)

Volume 7- No.6, November-December 2017

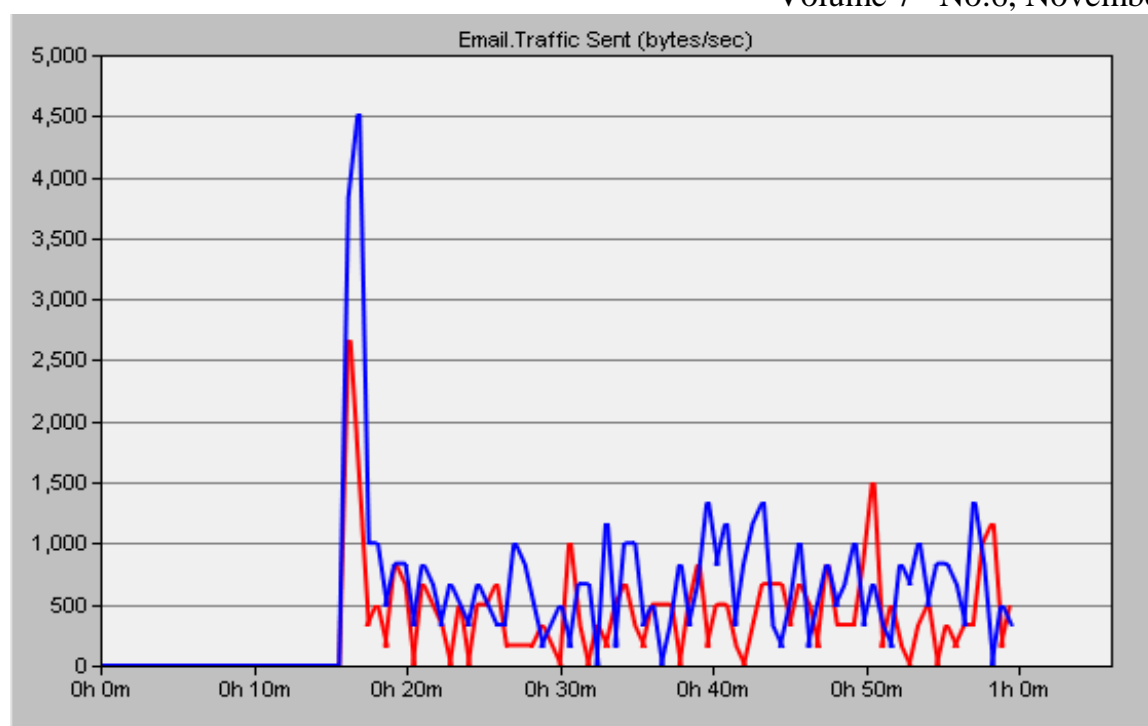

Fig2.Data traffic sent for E-mail

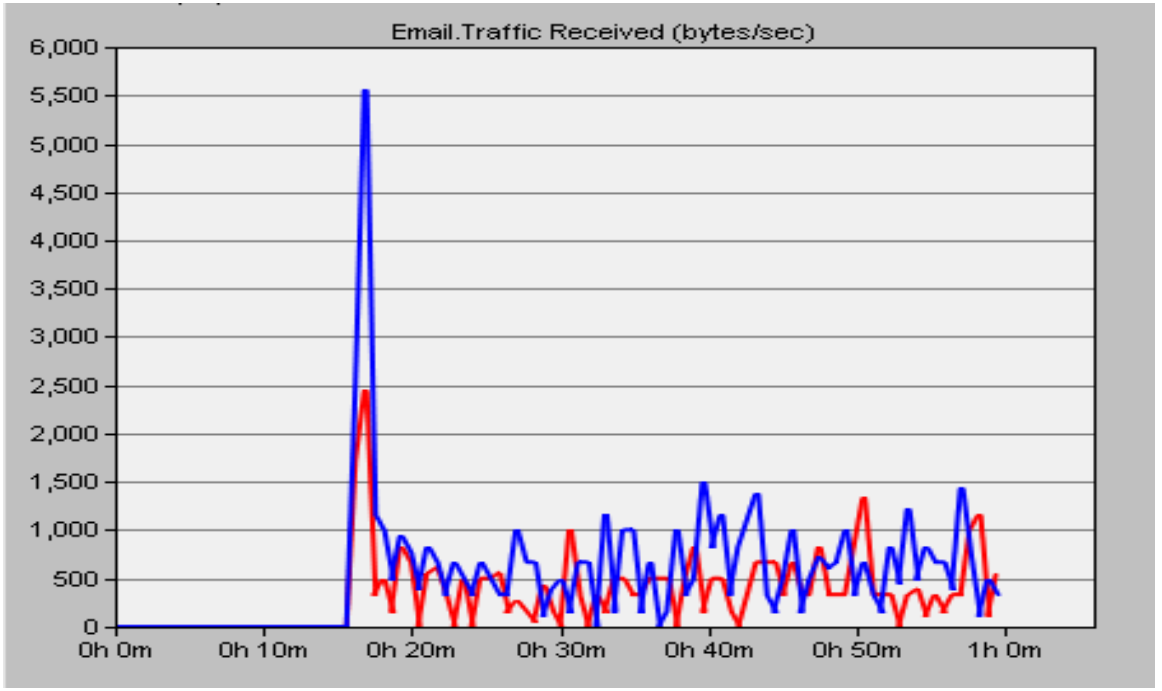

Fig3.Data traffic receive for E-mail

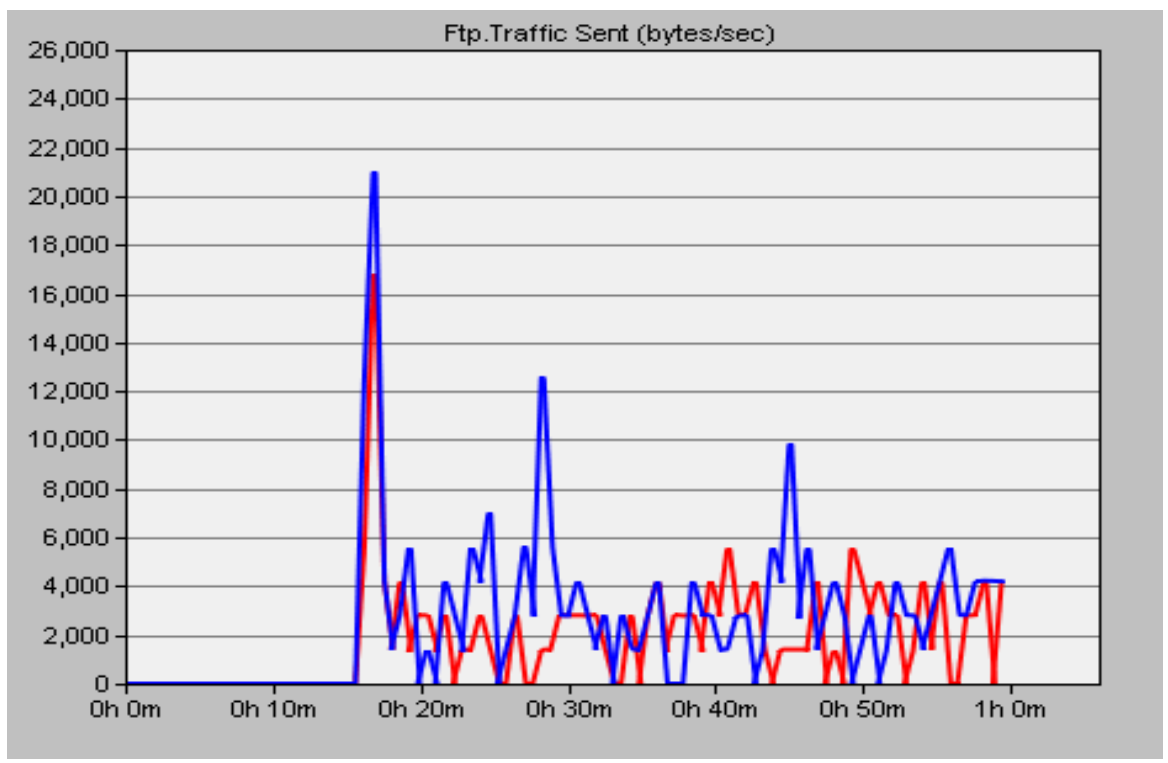

Fig4.Data traffic sent for FTP 
DOI: https://dx.doi.org/10.26808/rs.ca.i7v6.07 International Journal of Computer Application (2250-1797)

Volume 7- No.6, November-December 2017

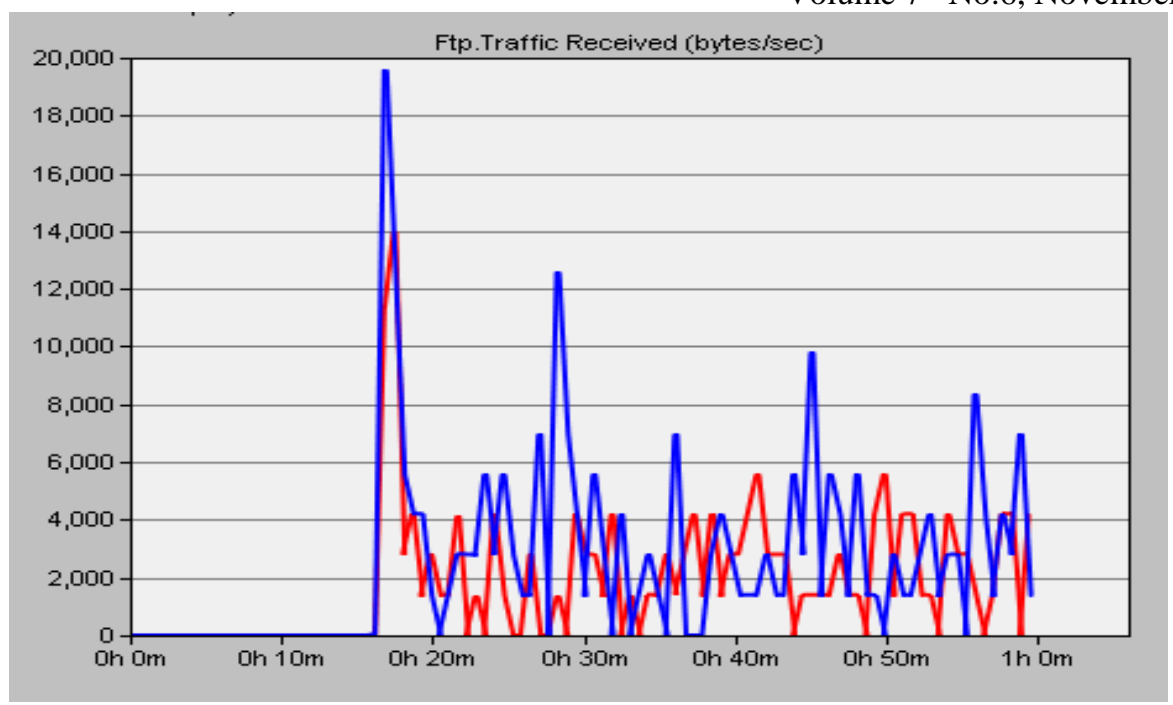

Fig5.Data traffic receive for FTP

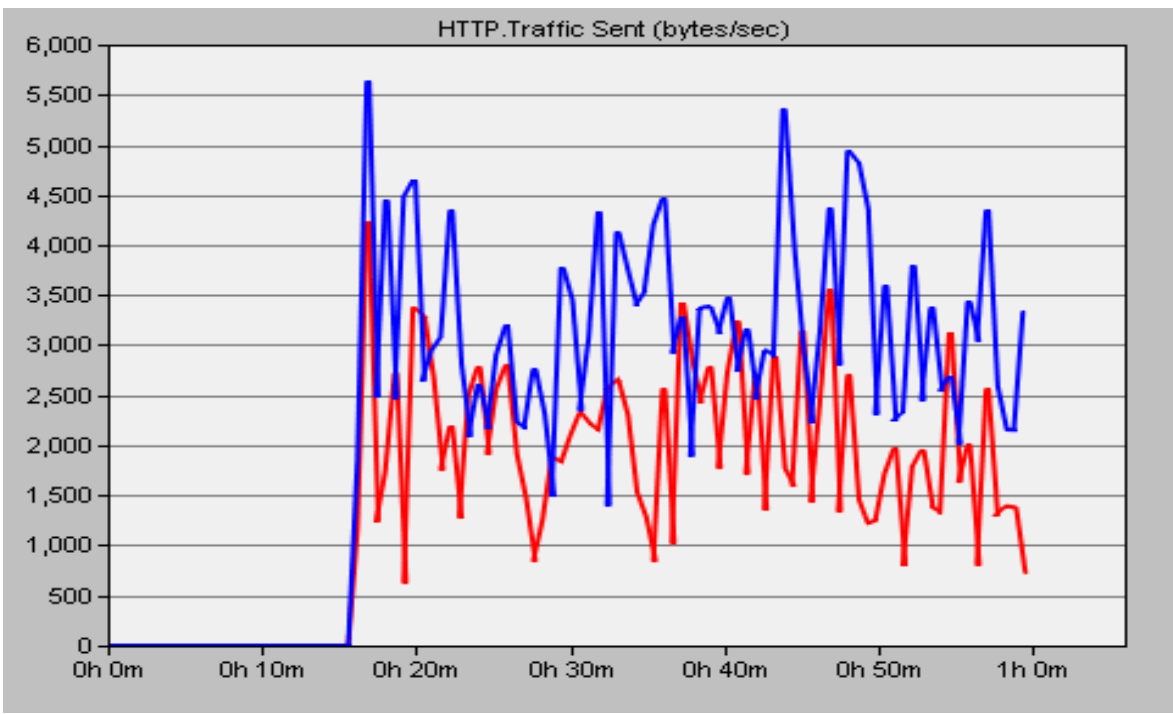

Fig6.Data traffic sent for HTTP

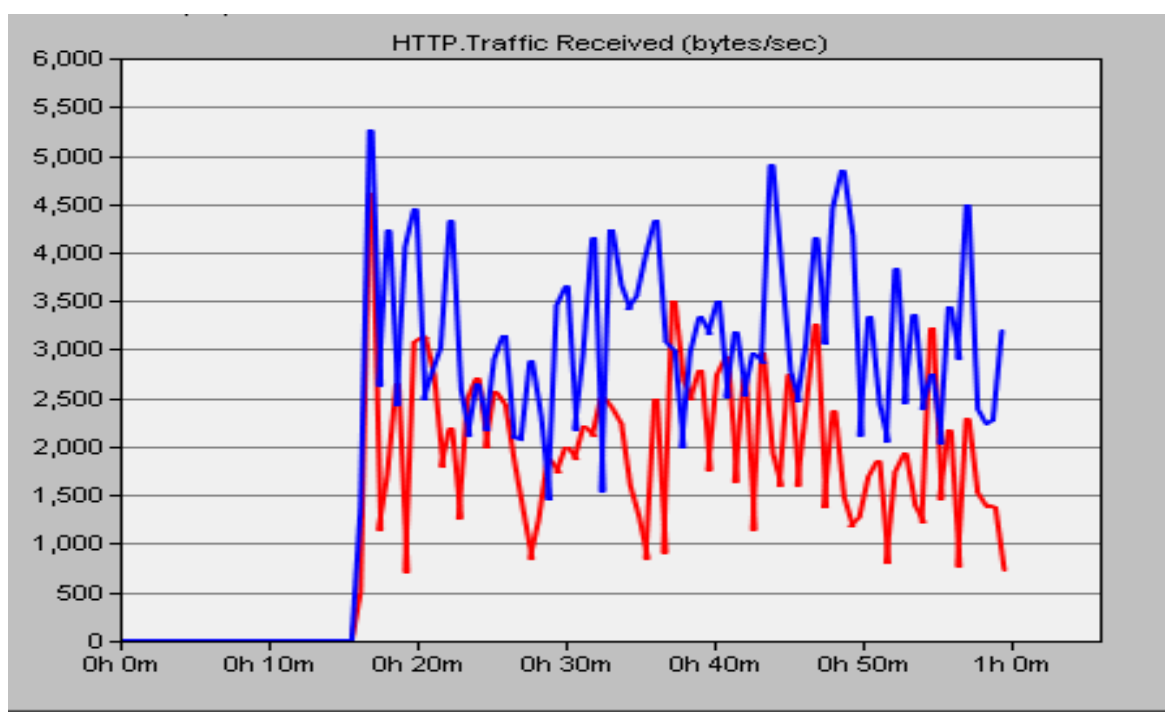

Fig7.Data traffic receive for HTTP 
DOI: https://dx.doi.org/10.26808/rs.ca.i7v6.07 International Journal of Computer Application (2250-1797)

Volume 7- No.6, November-December 2017

Table1. Comparison between UMTS performance metrics with handover support and without handover support

\begin{tabular}{|l|c|c|}
\hline \multicolumn{1}{|c|}{ UMTS Parameters } & With Handover Support & Without Handover Support \\
\hline Data traffic sent for E-mail & $4513 \mathrm{byte} / \mathrm{sec}$ & $2672 \mathrm{byte} / \mathrm{sec}$ \\
\hline Data traffic receive for E-mail & $5569 \mathrm{byte} / \mathrm{sec}$ & $2451 \mathrm{byte} / \mathrm{sec}$ \\
\hline Data traffic sent for FTP & $21018 \mathrm{byte} / \mathrm{sec}$ & $2672 \mathrm{byte} / \mathrm{sec}$ \\
\hline Data traffic receive for FTP & $19629 \mathrm{byte} / \mathrm{sec}$ & $13974 \mathrm{byte} / \mathrm{sec}$ \\
\hline Data traffic sent for HTTP & $5683 \mathrm{byte} / \mathrm{sec}$ & $4232 \mathrm{byte} / \mathrm{sec}$ \\
\hline Data traffic receive for HTTP & $5259 \mathrm{byte} / \mathrm{sec}$ & $4612 \mathrm{byte} / \mathrm{sec}$ \\
\hline
\end{tabular}

\section{Conclusions}

Three types of the traffic: FTP, HTTP, E-mail were investigated by UMTS network through two performance factors: : data traffic sent and data traffic receive by using OPNET modeler. The results represented that handover has an effect on UMTS signal that keep the signal in range (avoid call termination) when the UE transfer from one base station to another with an excellent connection.

\section{References}

[1] Sh. Acharya and T. Gaba, "Execution of Soft Handover in UMTS Using OPNET Simulator", International journal of Emerging Trends in Science and Technology,ISSN 2348-9480, Volume 01, Issue 03, Pages 326-331, May 2014.

[2] Tauseef Mubeen, Imran A.Tasadduq and Junaid A. Zubairi, "Hand Off Issues in 3G UMTS Networks", Proceedings of International Bhurban Conference on Applied Sciences \& Technology, Islamabad, Pakistan, 8th- 11th January, 2007.

[3] Dr. Ameen Babiker, Dr. HallaAhmmed and Salah Ali, "Comparative Study $1^{\text {st }}, 2^{\text {nd }}, 3^{\text {rd }}, 4^{\text {th }}$, Generations from Handoff Aspects", International Journal of Science and Research, ISSN 2319-7064, Volume 5 Issue 6, June 2016.

[4] H. NAWAZ et al., "Simulation Based Analysis of Handover Issues Affecting UMTS Performance", SINDH UNIVERSITY RESEARCH JOURNAL (SCIENCE SERIES), Vol. (45), Issue (4),September 2013.

[5] S.-W. Wang and I. Wang, "Effects of Soft Handoff, Frequency Reuse and Non-Ideal Antenna Sectorization on CDMA System Capacity",Proc. IEEE VTC, Secaucus, NJ, pp. 850-54, May 1993.

[6] Dr. JitendraKumawat and Shrinth Tailor, "Soft and Softer Handover in Communication Netwoks", International Journal on Recent and Innovation Trends in Computing and Communication, ISSN 2321 - 8169, Volume: 1, Issue: 6, Pages 558 - 562,JUNE 2013.

[7] Sher Ali, Nasir Saleem and Tayyaba Tareen, "Measuring the Performance of Handover Mechanisms in UMTS for Diverse Traffic Services Classes to Improve QoS", International Journal of Computer Applications, ISSN (0975 - 8887), Volume 55, No.11, October 2012.

[8] Ahmed A. Ahmed, Hawraa H. Abbas and Haider G. Al-Qurabi, "Evaluation and Comparison of Soft and Hard Handovers in Universal Mobile Telecommunication (UMTS) Networks ", Journal of Kerbala University, Vol. 8, No.1, Scientific 2010. 
DOI: https://dx.doi.org/10.26808/rs.ca.i7v6.07 International Journal of Computer Application (2250-1797)

Volume 7- No.6, November-December 2017

[9] Amandeep bhalla, Rumani Bhatia, Anil Dudy, "Implementation of Soft Handove $r$ in "3G" using OPNET", International journal of Emerging Trends in Science and Technology, ISSN 2348-9480, Volume 01, Issue 03, Pages 363-367, May 2014.

[10] Muhammad A. Rahman, Abu B. Bhatti and Ammar A. Kirmani, "Radio Resource Management In 3G UMTS Networks", Master thesis of Science in Electrical Engineering, November 2007.

[11] HarriHolma and Antti Toskala "WCDMA for UMTS: Radio Access for Third Generation Mobile Communication" $3^{\text {rd }}$ Edition, John Wiley \& Sons, ISBN 0-470-87096-6. 